\title{
Biodegradable yolk-shell microspheres for ultrasound/MR dual-modality imaging and controlled drug delivery
}

Peng Yang, ${ }^{\mathrm{a}, \mathrm{b}}$ Xianfu Luo, ${ }^{\mathrm{c}}$ Sheng Wang, ${ }^{\mathrm{d}}$ Fang Wang, ${ }^{\mathrm{a}}$ Chuanbing Tang, ${ }^{\mathrm{b}}$ and Changchun Wang ${ }^{\mathrm{a}, *}$

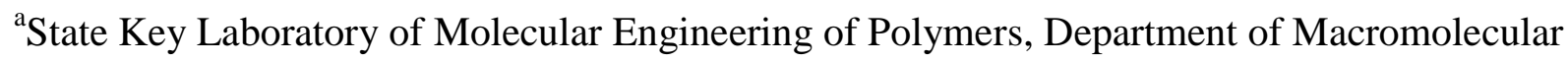
Science, and Laboratory of Advanced Materials, Fudan University, Shanghai, 200433, People's Republic of China.

${ }^{b}$ Department of Chemistry and Biochemistry, University of South Carolina, Columbia, South Carolina 29208, United States.

${ }^{c}$ Department Department of Radiology, Ruijin Hospital, Shanghai Jiaotong University, School of Medicine, Shanghai 200025, China.

${ }^{\mathrm{d}}$ Department of Colorectal Surgery, Shanghai Cancer Center, Fudan University, Shanghai 200032, China.

\section{Corresponding Author}

*Address correspondence to ccwang@ fudan.edu.cn; Tel/Fax number: +86-21-55664371/+86$21-65640293$ 
ABSTRACT: A new class of uniform biodegradable yolk-shell $\mathrm{Fe}_{3} \mathrm{O}_{4} @$ PFH@PMAA-DOX microspheres was developed as ultrasound/MR dual-modality imaging contrast agents and drug delivery system. PMAA shells exhibit excellent drug loading capability and efficiency, the DOX-loading capacity is $15.4 \mathrm{wt} \%$ and the drug loading efficiency is $91 \%$. In vivo ultrasound and MRI experiments indicate that the as-prepared $\mathrm{Fe}_{3} \mathrm{O}_{4} @$ PFH@PMAA-DOX microspheres successfully reach tumor tissues and possess robust dual-modality imaging capability, the $r_{2}$ value of MRI is $71.82 \mathrm{mM}^{-1} \mathrm{~s}^{-1}$. In vitro cytotoxicity and in vivo tissues biopsies show that the loaded DOX can be control-released under $\mathrm{pH}$, redox and ultrasound multi-stimuli and kill cancer cells effectively. Furthermore, disulfide-crosslinked PMAA shells and PGA-stabilized $\mathrm{Fe}_{3} \mathrm{O}_{4}$ cores can be respectively degraded into short hydrophilic polymer chains and iron ions, reducing their cumulative toxicity in organisms. Thus, the multifunctional biodegradable microspheres are safer for normal tissues and more beneficial in actual clinical applications.

KEYWORDS: Yolk-shell structure; dual-modality; ultrasound imaging; magnetic resonance imaging (MRI); controlled drug delivery 


\section{INTRODUCTION}

In recent years, significant efforts have been devoted to developing new technologies for early cancer diagnosis and therapy [1-3]. Despite the brilliant progress, the war on cancer is still ongoing and looks more complicated than what was in the past $[4,5]$. To obtain more detailed information about the disease, high-performance multi-imaging modalities have attracted much attention [6-12]. Specifically, a dual-modality imaging technique combining ultrasound (US) and magnetic resonance imaging (MRI), which can ally the high spatial resolution of MRI to the real-time of US, is quickly developed as a powerful tool to visualize an abnormal state of a body [13-16].

Employing multifunctional nanoparticles as imaging contrast agents not only enhances the signal of imaging but also offers a more accurate anatomical information, which can increase the intraoperative control and assessment in image-guided therapies [17-19]. On one hand, gas or liquid-filled (air, sulfur hexafluoride or perfluorocarbons) microbubbles (MBs) are often used as ultrasound contrast agents (UCA) [20-30]. On the other hand, owing to their large magnetic moment, superparamagnetic iron oxide (SPIO) nanoparticles are used for fabricating magnetic operation and $\mathrm{T}_{2}$-weighted $\mathrm{MRI}$ [31-37]. Thus, a number of SPIO nanoparticle-loaded MBs have emerged as contrast agents for US/MR dual-modality imaging investigations, and the size of the MBs is usually over microns, which will be hindrance its application as drug delivery carrier $[38-46]$

More importantly, a desirable carrier is that it could be released from the biologic system after carrying out the diagnostic or therapeutic functions [47]. Studies have shown that the particles with the size less than $5.5 \mathrm{~nm}$ could be cleared by the kidneys [48]. But the US/MRI contrast agents reported usually could not be degraded in the body due to the low degradability of crystallized SPIO nanoparticles and shell materials $[49,50]$. These limits may circumvent renal filtration and increase toxicity to 
patients $[51,52]$. Therefore, to enhance accumulation in target tumours and reduce the toxicity of carriers, developing biodegradable multifunctional nanoscale particles as contrast agents for US/MRI dual-modality imaging is highly desirable.

Our group has reported a new type of mesoporous magnetic $\mathrm{Fe}_{3} \mathrm{O}_{4}$ nanoclusters stabilized by $\operatorname{poly}\left(\gamma\right.$-glutamic acid) (PGA) [53]. The $\mathrm{Fe}_{3} \mathrm{O}_{4}$ nanoclusters not only possessed excellent colloidal stability and good biocompatibility, but also exhibited high saturation magnetization and prominent superparamagnetism. Importantly, they could be degraded into iron ions in an acidic cellular environment $(\mathrm{pH}=5.0)$. These nanoclusters can be used as ideal blocks for biodegradable multifunctional MRI contrast agents after coated with organic or inorganic shell. Meanwhile, we also demonstrated disulfide cross-linked biodegradable poly(methacrylic acid) (PMAA)based nanohydrogels and nanocapsules as an controlled drug delivery system (DDS) [54,55]. Owing to strong electrostatic interactions between the carboxyl group of PMAA and amino group of anti-carcinogen doxorubicin (DOX), these biocompatible nanomaterials had high drug loading capacity and excellent drug loading efficiency. They could be quickly degraded into short polymer chains using a water-soluble reducing agent glutathione (GSH), which widely exists in animal cells as the major redox compound to determine the antioxidative capacity of cells.

Herein we develop a new class of multi-responsive biodegradable yolk-shell magnetic microspheres for US/MRI dual-modality imaging and drug delivery system. The nanosystems consist of PGA-stabilized $\mathrm{Fe}_{3} \mathrm{O}_{4}$ nanoclusters as the magnetic core and disulfide cross-linkage PMAA as the functional shell. In order to obtain excellent ultrasound imaging diagnosis signal and therapeutic effects, we further introduce ultrasound-sensitive perfluorohextane (PFH) into the inner cavities of yolk-shell microspheres and load anti-cancer drug doxorubicin (DOX) in the PMAA shells. Such yolk-shell microspheres exhibit an obvious $\mathrm{pH}$, redox and ultrasound multi-responsive 
capability. They can be degraded into super short polymer chains and iron ions, and rapidly release DOX at the intracellular level $(\mathrm{pH}=5.0$ and $10 \mathrm{mM} \mathrm{GSH})$, meanwhile implementing minimal drug release under an extracellular condition ( $\mathrm{pH}=7.4$ and nonreductive). We demonstrate that the as-prepared yolk-shell microspheres can successfully reach the tumor tissues and serve as ideal contrast agents for US/MR dualmodality imaging. In addition, in vitro cell assays and in vivo tissue biopsies show the loaded DOX can be control-released in tumor tissues and further kill cancer cells. To our best knowledge, this is the first time using yolk-shell nanomaterials with both biodegradable cores and shells as US/MR dual-modality imaging contrast agents and controlled drug delivery system.

\section{EXPERIMENTAL SECTION}

\subsection{Materials.}

Iron(III) chloride hexahydrate $\left(\mathrm{FeCl}_{3} \cdot 6 \mathrm{H}_{2} \mathrm{O}\right)$, anhydrous ethanol, ethylene glycol (EG), ammonium acetate $\left(\mathrm{NH}_{4} \mathrm{OAc}\right)$ and $\mathrm{Poly}(\gamma$-glutamic acid) (PGA) were purchased from Shanghai Chemical Reagents Company (China) and used as received. Methacrylic acid (MAA) and N, N-bis(acryloyl)cystamine (BACy) were purchased from Sigmae Aldrich. Acetonitrile (AN) was purchased from Shanghai Lingfeng Chemical Reagent Company, and dried with calcium hydride and purified by reflux before use. Cystamine dihydrochloride and perfluorohexane (PFH) were purchased from Acros Organics. Acryloyl chloride, glutathione (GSH) was purchased from Shanghai Aladdin Chemistry Company. 2, 2azobisisobutyronitrile (AIBN) was obtained from Sinopharm Chemical Reagent Company and recrystallized from ethanol. Doxorubicin (DOX) hydrochloride salt was obtained from Beijing Huafeng United Technology Company. Ethyl acetate, heptane and dichloromethane were obtained from Shanghai Chemical Reagents Company and used without a further purification. Deionized water was used in all our experiments. 


\subsection{Characterization.}

SEM images were obtained using a TS-5136MM (TESCAN, Czech) scanning electron microscope at an accelerating voltage of $20 \mathrm{kV}$. TEM images were performed on an H-600 (Hitachi, Japan) transmission electron microscope at an accelerating voltage of $75 \mathrm{kV}$. FTIR spectra were recorder on a Magna-550 (Nicolet, USA) spectrometer. The samples were dried and mixed with $\mathrm{KBr}$ to be compressed to a plate for measurement. Hydrodynamic diameter measurements were conducted by dynamic light scattering (DLS) with a ZEN3600 (Malvern, UK) Nano-ZS instrument. Magnetic characterization was carried out on a Model 6000 physical property measurement system (Quantum Design, USA) at $300 \mathrm{~K}$. TGA data were obtained with a Pyrisis-1 (Perkin-Elmer, USA) thermal analysis system under a flowing nitrogen atmosphere at a heating rate of $20^{\circ} \mathrm{C} / \mathrm{min}$ from 100 to $800^{\circ} \mathrm{C}$. ICP atomic emission spectrometry was conducted by a P-4010 (Hitachi, Japan) spectrometer. Ultrasound images under B mode and power Doppler mode were carried out on a color digital ultrasonic diagnostic apparatus GE LOGIQ Book XP and MRI experiment was performed on a $3 \mathrm{~T}$ Siemens Magnetom Trio.

\subsection{Synthesis of $\mathrm{PGA}$-modified $\mathrm{Fe}_{3} \mathrm{O}_{4}$ nanoclusters.}

The PGA-modified $\mathrm{Fe}_{3} \mathrm{O}_{4}$ nanoclusters were prepared through a modified solvothermal reaction [53]. Typically, PGA $(0.50 \mathrm{~g}), \mathrm{FeCl}_{3} \cdot 6 \mathrm{H}_{2} \mathrm{O}(1.35 \mathrm{~g}, 5 \mathrm{mmol})$ and $\mathrm{NH}_{4} \mathrm{Ac}(3.85 \mathrm{~g}$, $0.05 \mathrm{~mol})$ were dissolved in ethylene glycol $(70 \mathrm{~mL})$. The mixture was stirred vigorously for 1 h at $160{ }^{\circ} \mathrm{C}$ under the protection of $\mathrm{N}_{2}$ and then transferred into a Teflon-lined stainless-steel autoclave. The mixture was heated to $200{ }^{\circ} \mathrm{C}$ for $15 \mathrm{~h}$ and cooled to room temperature. The black PGA-modified $\mathrm{Fe}_{3} \mathrm{O}_{4}$ nanoclusters were then washed three times with ethanol and water to effectively remove the solvent and separated from the supernatant by using magnetic force during each washing step.

2.4 Preparation of biodegradable yolk-shell $\mathrm{Fe}_{3} \mathrm{O}_{4} @ P M A A$ microspheres. 
First, the core/shell $\mathrm{Fe}_{3} \mathrm{O}_{4} @ \mathrm{u}-\mathrm{PMAA}$ microspheres were prepared by using the refluxprecipitation polymerization [55,56]. Typically, PGA-modified $\mathrm{Fe}_{3} \mathrm{O}_{4}$ nanoclusters $(100 \mathrm{mg})$, MAA (500 mg, $5.808 \mathrm{mmol})$, and AIBN (16.0 mg, $0.1 \mathrm{mmol})$ were dissolved in $40 \mathrm{~mL}$ of acetonitrile (AN) in a dried 50-mL single-necked flask with the aid of ultrasound for $10 \mathrm{~min}$. Then, the reaction mixture was heated $110{ }^{\circ} \mathrm{C}$ and maintained for $3 \mathrm{~h}$. The obtained $\mathrm{Fe}_{3} \mathrm{O}_{4} @ \mathrm{u}-$ PMAA microspheres were then rinsed several times with ethanol under ultrasonic conditions to effectively remove the solvent and separated from the supernatant by using magnetic force during each rinsing step. Then, the $\mathrm{Fe}_{3} \mathrm{O}_{4} @ \mathrm{u}-\mathrm{PMAA}$ microspheres were dispersed in $\mathrm{AN}$ as seeds to synthesize disulfide-crosslinked PMAA (d-PMAA) coated $\mathrm{Fe}_{3} \mathrm{O}_{4} @$ u-PMAA@dPMAA core-shell microspheres by using the same reflux-precipitation polymerization: $\mathrm{Fe}_{3} \mathrm{O}_{4} @ \mathrm{u}-\mathrm{PMAA}(100 \mathrm{mg}), \mathrm{BACy}(200 \mathrm{mg}, 0.77 \mathrm{mmol}), \mathrm{MAA}(500 \mathrm{mg}, 5.808 \mathrm{mmol})$, and AIBN (16.0 mg, $0.1 \mathrm{mmol}$ ) were dissolved in $40 \mathrm{~mL}$ of acetonitrile (AN) in a dried $50-\mathrm{mL}$ single-necked flask. Finally, the yolk-shell $\mathrm{Fe}_{3} \mathrm{O}_{4} @$ PMAA microspheres were obtained by dispersed $\mathrm{Fe}_{3} \mathrm{O}_{4} @ \mathrm{u}-\mathrm{PMAA} @ \mathrm{~d}-\mathrm{PMAA}$ in ethanol for $3 \mathrm{~h}$ to remove uncrosslinked PMAA cores and then rinsed several times with ethanol and freeze-dried for $48 \mathrm{~h}$ in vacuum freezedryer.

\subsection{Preparation of $\mathrm{Fe}_{3} \mathrm{O}_{4} @ \mathrm{PFH} @ \mathrm{PMAA}-\mathrm{DOX}$ microspheres.}

Anti-cancer drug DOX was chosen as a model drug to investigate the drug loading and controlled release behavior. Typically, dry yolk-shell $\mathrm{Fe}_{3} \mathrm{O}_{4} @$ PMAA microspheres (10 mg) and $6 \mathrm{mg}$ of DOX (6 mg) were dispersed in $20 \mathrm{~mL}$ of phosphate buffer solution (PBS) (pH 7.4) and stirred for $24 \mathrm{~h}$ at room temperature. The conjugate was then centrifuged to collect $\mathrm{Fe}_{3} \mathrm{O}_{4} @ \mathrm{PMAA}-\mathrm{DOX}$ sediments and washed with PBS ( $\mathrm{pH}$ 7.4) for three times to remove the surface adsorbed DOX. The sample was obtained by centrifugation and freeze-dried for $48 \mathrm{~h}$ in vacuum. The DOX loading capacity was calculated by a UV visible spectrophotometer at $480 \mathrm{~nm}$ and a standard DOX calibration curve. Then, freeze-dried yolk-shell $\mathrm{Fe}_{3} \mathrm{O}_{4} @ \mathrm{PMAA}-$ DOX microspheres $(30 \mathrm{mg})$ were stored in a $5 \mathrm{~mL}$ bottle and infused dropwise with highly 
echogenic PFH liquid $(200 \mu \mathrm{L})$. The bottle was sonicated in ice water for 5 min to facilitate the PFH loading in microspheres. Then $\mathrm{Fe}_{3} \mathrm{O}_{4} @ \mathrm{PFH} @$ PMAA-DOX was dispersed in deionized water $(25 \mathrm{~mL})$ under slight stirring for $2 \mathrm{~h}$ at room temperature. After centrifuged at 10,000 rpm for 5 min., the obtained $\mathrm{Fe}_{3} \mathrm{O}_{4} @$ PFH@PMAA-DOX microspheres were dispersed in PBS $(10 \mathrm{~mL})$ for further experimentations.

\subsection{The degradablity of yolk-shell $\mathrm{Fe}_{3} \mathrm{O}_{4} @ P M A A$ microspheres.}

Yolk-shell $\mathrm{Fe}_{3} \mathrm{O}_{4} @$ PMAA microspheres $\left(30 \mathrm{mg}\right.$ ) were dispersed in $\mathrm{Na}_{3} \mathrm{Cit} / \mathrm{H}_{3} \mathrm{Cit}$ buffer $(\mathrm{pH}=5.0,150 \mathrm{~mL} 0.1 \mathrm{M})$ with $\mathrm{GSH}(10 \mathrm{mM})$, and then was divided into fifteen equal parts in glass bottle by shaking in table concentrator at $160 \mathrm{rpm}$. The sample was taken out one by one in an interval of about $10 \mathrm{~h}$. After magnetic separation by an external magnetic field, supernatant $(8 \mathrm{~mL})$ was extracted and the concentration of the components in solution was detected by UV absorption spectrum and inductively coupled plasma (ICP) spectroscopy. The molecular weight of the degraded polymers from the PMAA shells was measured in $\mathrm{NaNO}_{3}$ aqueous solutionn (0.1 M) by Gel Permeation Chromatography (GPC).

\subsection{In vitro drug release test.}

Typically, the $\mathrm{Fe}_{3} \mathrm{O}_{4} @$ PMAA-DOX $(10 \mathrm{mg})$ was dispersed in of two different buffer solutions (10 mL, phosphate buffer for $\mathrm{pH} 7.4$ and acetate buffer for $\mathrm{pH} 5.0$,), and the dispersion was divided into five equal aliquots. Each aliquot sample $(2 \mathrm{~mL})$ was then transferred into a dialysis bag (molecular weight cut off 14,000), which were dialyzed against the corresponding buffer ( $80 \mathrm{~mL}, \mathrm{pH}=7.4$ or 5.0$)$ with or without $\mathrm{GSH}(10 \mathrm{mM})$ and gently shaken $(200 \mathrm{rpm})$ at $37^{\circ} \mathrm{C}$ in shaking table. The drug release was assumed to start as soon as the dialysis bags were placed into the reservoir. At predetermined intervals, $3 \mathrm{~mL}$ of the solution was obtained periodically from the reservoir, and the amounts of released DOX were analyzed by UV-vis at $480 \mathrm{~nm}$. For keeping a constant volume, $3 \mathrm{~mL}$ of fresh buffer medium was added back to the reservoir after each sampling.

\subsection{In vitro cell assays.}


The cytotoxicity assay of free DOX, pure $\mathrm{Fe}_{3} \mathrm{O}_{4} @$ PMAA and $\mathrm{Fe}_{3} \mathrm{O}_{4} @$ PMAA-DOX was performed by cell counting kit-8 (CCK-8) assay (Dojindo, Japan). The HPAC cells were grown in Dulbecco's modified Eagle's medium (DMEM) supplemented with $10 \%$ heatinactivated fetal bovine serum, streptomycin $\left(100 \mathrm{U} \mathrm{mL}^{-1}\right)$ and penicillin $\left(100 \mathrm{U} \mathrm{mL}^{-1}\right)$ with $5 \% \mathrm{CO}_{2}$ at $37{ }^{\circ} \mathrm{C}$. Cells were seeded onto 96-well plates (10, 000 cells well $\left.{ }^{-1}\right)$ and incubated for $24 \mathrm{~h}$ in a humidified atmosphere with $5 \% \mathrm{CO}_{2}$ at $37{ }^{\circ} \mathrm{C}$. The HPAC cells were washed with PBS, and the medium was replaced with a fresh medium containing free DOX or $\mathrm{Fe}_{3} \mathrm{O}_{4} @ \mathrm{PMAA}$ or $\mathrm{Fe}_{3} \mathrm{O}_{4} @ \mathrm{PMAA}-\mathrm{DOX}$ of known concentrations. After $24 \mathrm{~h}$ and $48 \mathrm{~h}$, the cells were washed with PBS and incubated in $100 \mathrm{~mL}$ DMEM containing 10m L CCK-8 solution for another $1 \mathrm{~h}$. The absorbance of each well was measured by a micro-plate reader (model FL 311, Bio-Tek Instruments, Winooski, VT, USA) at the $450 \mathrm{~nm}$ wavelength. The results were expressed as mean values of four measurements. Since the absorbance is proportional to the number of viable cells in the medium, the cell viability was determined by using a previously prepared calibration curve.

The cytotoxicity analysis of pure $\mathrm{Fe}_{3} \mathrm{O}_{4} @ \mathrm{PMAA}$ microspheres to HEK 293 cells was conducted the same way mentioned above.

\subsection{Confocal laser scanning microscopy (CLSM) observation.}

The cellular uptake of the $\mathrm{Fe}_{3} \mathrm{O}_{4} @$ PMAA-DOX was confirmed by confocal laser scanning microscopy (CLSM) observation. The HPAC cells were seeded in 6-well culture plates (a clean cover slip was put in each well) and grown, overnight, as a monolayer, and were incubated with $\mathrm{Fe}_{3} \mathrm{O}_{4} @$ PMAA-DOX at $37{ }^{\circ} \mathrm{C}$ for $2 \mathrm{~h}, 6 \mathrm{~h}, 12 \mathrm{~h}$ and $24 \mathrm{~h}$. Thereafter, the cells were rinsed with PBS three times, fixed with $2.5 \%$ formaldehyde $\left(1 \mathrm{~mL}\right.$ per well) at $37{ }^{\circ} \mathrm{C}$ for 10 min, and then rinsed with PBS three times again. To perform nucleus labeling, the nuclei was stained with Hoechst 33342 solution (from Molecular Probes, $20 \mathrm{~m} \mathrm{gmL}^{-1}$ in PBS, $1 \mathrm{~mL}$ per well) for $10 \mathrm{~min}$ and then rinsed with PBS three times. The cover slips were placed on a glass microscope slide, and the samples were visualized using CLSM (Olympus, FV10-ASW). 


\subsection{In vitro ultrasound and MR imaging.}

In vitro ultrasound images for PBS control, yolk-shell $\mathrm{Fe}_{3} \mathrm{O}_{4} @ \mathrm{PMAA}$ and $\mathrm{Fe}_{3} \mathrm{O}_{4} @ \mathrm{PFH} @$ PMAA-DOX microspheres were carried out under B mode and power Doppler mode Typically, phosphate buffered solution (PBS, $20 \mathrm{~mL}$ ) with constant concentration of samples $\left(4 \mathrm{mg} \mathrm{mL}^{-1}\right)$ was filled into a dialysis bag $(2.5 \mathrm{~cm} \times 10.0 \mathrm{~cm})$. The ultrasound imaging was achieved by using 8L-RS probe (4-10 MHz, linear array) with PRF of $100 \mathrm{~Hz}$, pressure amplitude of 1.0 MPa, frequencies of $4 \mathrm{MHz}$, and $\mathrm{MI}$ of 0.4 for $\mathrm{B}$ mode and 1.1 for power Doppler mode at $40 \%$ power. The transducer was coated with ultrasound gel to avoid air back-ground. All images were recorded as digital files for subsequent playback and analysis. The average gray scale was calculated by averaging the gray scale levels of all pixels within an indicated region of interest (RIO).

The $\mathrm{T}_{2}$-weighted MR images were acquired using a $3 \mathrm{~T}$ Siemens Magnetom Trio running on Siemens' Syngo software version B15 (Siemens Medical Systems). Dilutions of $\mathrm{Fe}_{3} \mathrm{O}_{4} @ \mathrm{PFH} @$ PMAA-DOX with different Fe concentrations (Fe concentration measured by ICP) in agarose solution ( $2 \mathrm{wt} \%$ ) were placed in a series of $2 \mathrm{~mL}$ tubes for $\mathrm{T}_{2}$-weighted $\mathrm{MR}$ imaging. The following parameters were adopted: $\mathrm{T}_{2}$-weighted spin-echo sequence, field of view (FOV) read of $180 \mathrm{~mm}$, an echo time (TE) of $19 \mathrm{~ms}$, repetition time (TR) of $3000 \mathrm{~ms}$, section thickness of $2.0 \mathrm{~mm}$, base resolution of 320 and number of acquisitions of 1 . Relaxivity values of $r_{2}$ were calculated through the curve fitting of $1 / T_{2}$ relaxation time $\left(\mathrm{s}^{-1}\right)$ versus the Fe concentration (mM).

\subsection{In vivo ultrasound and MR imaging.}

Animal procedures were in agreement with the guidelines of the regional ethic committee for animal experiments. The nude mice bearing pancreatic tumor (around 200-300 $\mathrm{g}$ of body weight) were obtained from Shanghai laboratory animal research center and were fasted for $24 \mathrm{~h}$ before experiments. The mice were anesthetized using $10 \%$ chloral hydrate and fixed at the ultrasound therapy system. Then, 2 mL PBS blank or $\mathrm{Fe}_{3} \mathrm{O}_{4} @$ PFH@PMAA-DOX (0.5 
$\mathrm{mg} / \mathrm{mL}$ ) PBS solution was injected via tail vein. The scanning parameter settings were the same as for the in vitro experiments. The livers and tumor regions of the nude mice were scanned before and after the administration of the as-prepared $\mathrm{Fe}_{3} \mathrm{O}_{4} @$ PFH@PMAA-DOX microspheres.

\subsection{Tumor histological biopsies analysis and TEM observation.}

The $\mathrm{Fe}_{3} \mathrm{O}_{4} @ \mathrm{PFH} @$ PMAA-DOX microspheres PBS solution (2 ml, $0.5 \mathrm{mg} / \mathrm{mL}$ ) was injected to pancreatic cancer in nude mice and then killed the mice after 72 hours. The histological biopsies of tissue section was stained with hematoxylin-eosin (H\&E) and observed under optical microscope. The TEM slice of tumor was scanned by Hitachi/JEOL $1230 \mathrm{H}-600$ transmission electron microscope to obtain the distribution of microspheres in the tumor cells.

\section{RESULTS AND DISCUSSION}

\subsection{Synthesis of biodegradable $\mathrm{Fe}_{3} \mathrm{O}_{4} @ P F H @ P M A A-D O X$ microspheres}

The entire process of fabricating biodegradable $\mathrm{Fe}_{3} \mathrm{O}_{4} @$ PMAA microspheres is demonstrated in Scheme 1a. First, the poly( $\gamma$-glutamic acid) (PGA)-stabilized $\mathrm{Fe}_{3} \mathrm{O}_{4}$ nanoclusters prepared via a solvothermal method as the seeds were uniformly coated with a layer of uncrosslinked PMAA (u-PMAA) to form a core-shell structure by using reflux-precipitation polymerization. Then, the $\mathrm{Fe}_{3} \mathrm{O}_{4} @ \mathrm{u}$-PMAA microspheres were further coated with a new layer of disulfite-croslinked PMAA (d-PMAA) using N, Nbis(acryloyl)cystamine (BACy) as a crosslinker to synthesize $\mathrm{Fe}_{3} \mathrm{O}_{4} @ \mathrm{u}-\mathrm{PMAA} @ \mathrm{~d}$ PMAA microspheres using the same polymerization method. Finally, the yolk-shell $\mathrm{Fe}_{3} \mathrm{O}_{4} @ \mathrm{PMAA}$ microspheres were prepared by dispersing $\mathrm{Fe}_{3} \mathrm{O}_{4} @ \mathrm{u}-\mathrm{PMAA} @ \mathrm{~d}-$ PMAA in ethanol to selectively dissolve the u-PMAA layer. In order to achieve the dual effect of diagnosis and therapy, the yolk-shell $\mathrm{Fe}_{3} \mathrm{O}_{4} @$ PMAA microspheres were first loaded with anticancer drug DOX in their shells through strong electrostatic 
interactions, and then filled with acoustic sensitive perfluorohexane (PFH) in the inner cavities by a mild infusion procedure (noted as $\mathrm{Fe}_{3} \mathrm{O}_{4} @ \mathrm{PFH} @ \mathrm{PMAA}-\mathrm{DOX}$ ). When the $\mathrm{Fe}_{3} \mathrm{O}_{4} @ \mathrm{PFH} @$ PMAA-DOX microspheres were administrated into the vessel of animals (Scheme 1b), the trace of microspheres in the body was monitored by using US and MRI dual-modality imaging techniques. At the same time, the ultrasound energy could induce PFH into small bubbles to enhance ultrasound signal and increase the permeability of vessel [57]. The microspheres could effectively penetrate through the permeabilized vessel to tumor tissues with the help of ultrasound and then accumulate in the tumor via the enhanced permeability and retention (EPR) effect [58]. Once the microspheres entered cancer cells, the PMAA shells could degrade into short polymer chains under glutathione (GSH) reduction condition and then release drug DOX to kill tumor cells. Meanwhile, the $\mathrm{Fe}_{3} \mathrm{O}_{4}$ cores were also degraded into iron ions in the acidic cellular environment, resulting effectively elimination from the body.

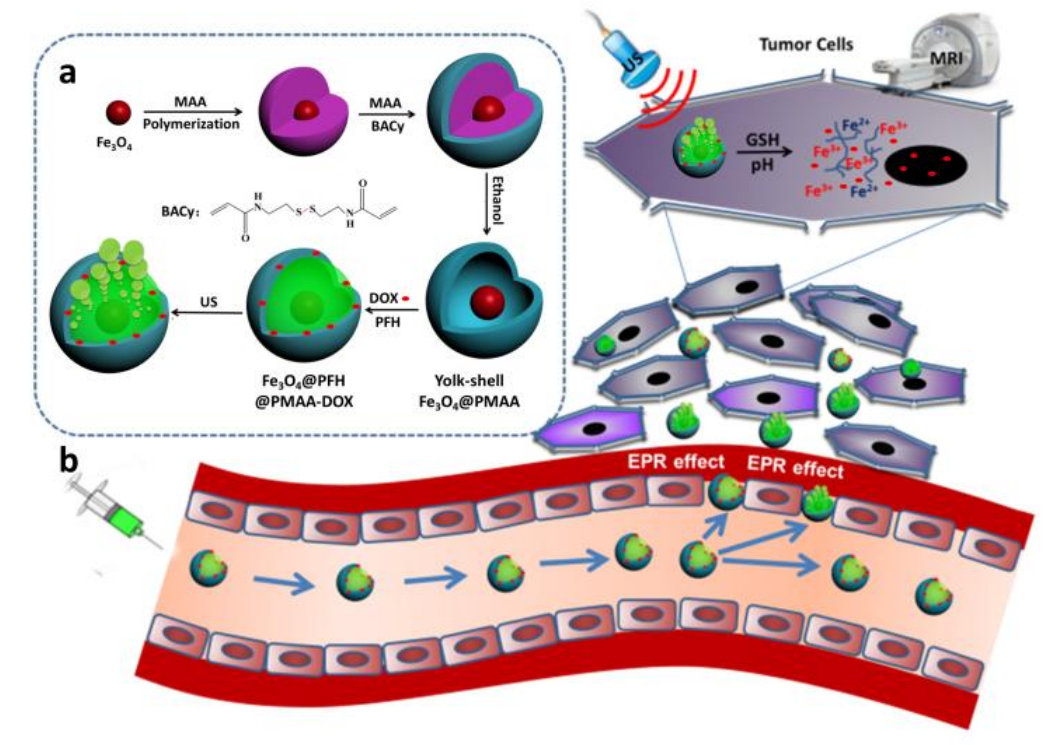

Scheme 1. (a)Schematic illustration of the preparation of uniform biodegradable yolkshell $\mathrm{Fe}_{3} \mathrm{O}_{4} @$ PFH@PMAA-DOX microspheres; (b) Schematic setup for US and MRI dual-modality imaging and drug delivery system using $\mathrm{Fe}_{3} \mathrm{O}_{4} @$ PFH@PMAA-DOX microspheres. 


\subsection{Characterization of biodegradable yolk-shell $\mathrm{Fe}_{3} \mathrm{O}_{4} @ P M A A$ microspheres}

The PGA-stabilized $\mathrm{Fe}_{3} \mathrm{O}_{4}$ nanoclusters were synthesized via a solvothermal reaction with $\mathrm{FeCl} .6 \mathrm{H}_{2} \mathrm{O}$ as a precursor, PGA as an electrostatic stabilization agent, $\mathrm{NH}_{4} \mathrm{Ac}$ as a foaming agent and ethylene glycol as a reducing agent. Transmission electron microscope (TEM) image (Fig. 1a) illustrated that the PGA-stabilized magnetic nanoclusters owned a distinct mesoporous structure with uniform size and shape. Scanning electron microscope (SEM) image (Fig. 1b) further confirmed the clusters were aggregated by the small primary $\mathrm{Fe}_{3} \mathrm{O}_{4}$ nanocrystals. In order to obtain well-defined yolk-shell magnetic microspheres with large cavities, a thick layer of uncrosslinked PMAA (u-PMAA) and a thin layer of disulfite-croslinked PMAA (dPMAA) were successively deposited onto the surface of $\mathrm{Fe}_{3} \mathrm{O}_{4}$ to form trilayered composite nanostructure $\left(\mathrm{Fe}_{3} \mathrm{O}_{4} @\right.$ u-PMAA@d-PMAA) by using reflux-precipitation polymerization. Finally, the middle uncrosslinked PMAA layer could be etched away easily under ethanol conditions, forming huge cavities between the d-PMAA shell and $\mathrm{Fe}_{3} \mathrm{O}_{4}$ core, while the d-PMAA shell part could be kept integrated due to high degree of crosslinking. As expected, the obtained yolk-shell $\mathrm{Fe}_{3} \mathrm{O}_{4} @$ PMAA microspheres exhibited excellent monodisperse hollow structures with an average diameter of 380 $\mathrm{nm}$ and $\mathrm{Fe}_{3} \mathrm{O}_{4}$ cores of about $120 \mathrm{~nm}$; the thickness of the shell was approximately 20$25 \mathrm{~nm}$ (Fig. 1c). The dynamic light scatting (DLS) measurement showed that the yolkshell $\mathrm{Fe}_{3} \mathrm{O}_{4} @$ PMAA nanospheres could be well swollen in water and owned hydrodynamic diameter of $840 \mathrm{~nm}$ with a narrow size distribution (PDI=0.135), while $\mathrm{Fe}_{3} \mathrm{O}_{4}$ cores kept the similar size with TEM (about $160 \mathrm{~nm}$ ) in water (Table 1). The Zeta potentials of $\mathrm{Fe}_{3} \mathrm{O}_{4}$ cores and $\mathrm{Fe}_{3} \mathrm{O}_{4} @$ PMAA nanospheres are both very negative around $-70 \mathrm{mV}$. The SEM image revealed that the yolk-shell $\mathrm{Fe}_{3} \mathrm{O}_{4} @ \mathrm{PMAA}$ 
microspheres possessed a concave morphology and an "erythrocyte-like" appearance, which was caused by the collapse of soft PMAA shell under high vacuum (Fig. 1d).

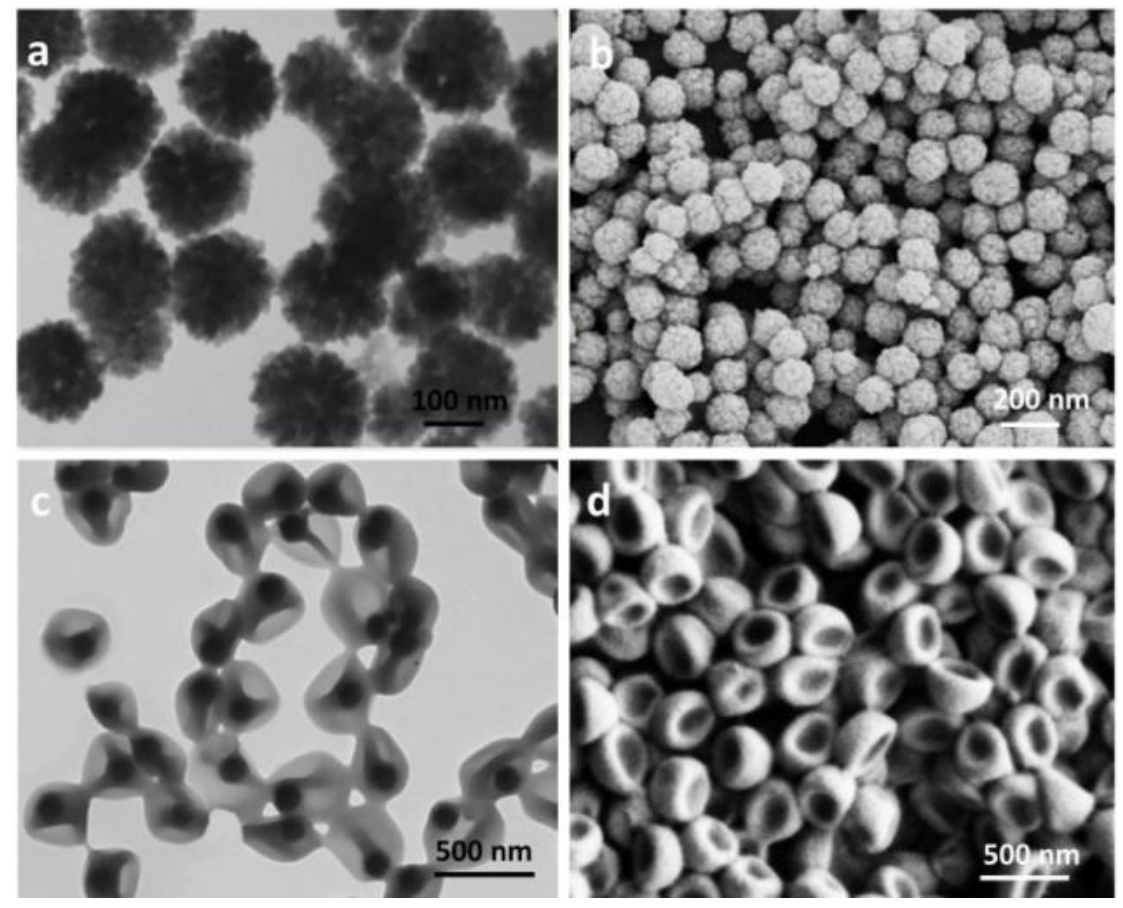

Fig. 1. TEM images and SEM images of $(\mathrm{a}, \mathrm{b}) \mathrm{PGA}$-stabilized $\mathrm{Fe}_{3} \mathrm{O}_{4}$ nanoclusters and (c, d) yolk-shell $\mathrm{Fe}_{3} \mathrm{O}_{4} @$ PMAA microspheres.

Table 1. Characterization of the PGA-stabilized $\mathrm{Fe}_{3} \mathrm{O}_{4}$ nanoclusters and yolk-shell $\mathrm{Fe}_{3} \mathrm{O}_{4} @$ PMAA microspheres.

\begin{tabular}{ccccc}
\hline Sample & Size $_{\text {TEM }}$ & Size $_{\text {DLS }}$ & PDI & Zeta Potential \\
\hline $\mathbf{F e}_{3} \mathbf{O}_{4}$ nanoclusters & $120 \mathrm{~nm}$ & $160 \mathrm{~nm}$ & 0.156 & $-76 \mathrm{mV}$ \\
$\mathbf{F e}_{3} \mathbf{O}_{\mathbf{4}} @$ PMAA & $380 \mathrm{~nm}$ & $840 \mathrm{~nm}$ & 0.135 & $-70 \mathrm{mV}$ \\
\hline
\end{tabular}

The chemical components of yolk-shell $\mathrm{Fe}_{3} \mathrm{O}_{4} @$ PMAA was identified by FTIR spectroscopy (Fig. 2a). The bands at 1630 and $1421 \mathrm{~cm}^{-1}$ corresponding to carboxylate group indicated the presence of PGA on the surface of $\mathrm{Fe}_{3} \mathrm{O}_{4}$ nanoclusters. The peaks at 573 and $438 \mathrm{~cm}^{-1}$ from the $\mathrm{Fe}-\mathrm{O}$ stretching, and a broad band at $3430 \mathrm{~cm}^{-1}$ attributed to the $\mathrm{O}-\mathrm{H}$ vibration confirmed the existence of $\mathrm{Fe}_{3} \mathrm{O}_{4}$. Besides the characteristic peaks 
of $\mathrm{Fe}_{3} \mathrm{O}_{4}$ nanoclusters, the typical amide $\mathrm{I}\left(1650 \mathrm{~cm}^{-1}\right)$ and amide II $\left(1550 \mathrm{~cm}^{-1}\right)$ bands of disulfide-bond BACy crosslinker and the $\mathrm{C}=\mathrm{O}$ stretching vibration of MAA were all found for the yolk-shell $\mathrm{Fe}_{3} \mathrm{O}_{4} @$ PMAA microspheres, suggesting that the PMAA shells consisted of disulfide bond and MAA monomer, rather than only MAA. Thermal gravimetric analysis (TGA) data suggested the magnetic content in the yolk-shell $\mathrm{Fe}_{3} \mathrm{O}_{4} @$ PMAA microspheres was about 67\% (Fig. 2b). Meanwhile, the magnetic characterization of $\mathrm{Fe}_{3} \mathrm{O}_{4}$ nanoclusters and yolk-shell $\mathrm{Fe}_{3} \mathrm{O}_{4} @$ PMAA microspheres was conducted at $300 \mathrm{~K}$ by a vibrating sample magnetometer (VSM, Fig. 2c). It showed that the saturation magnetization values of $\mathrm{Fe}_{3} \mathrm{O}_{4}$ nanoclusters and $\mathrm{Fe}_{3} \mathrm{O}_{4} @$ PMAA microspheres was $69.8 \mathrm{emu} / \mathrm{g}$ and $47.3 \mathrm{emu} / \mathrm{g}$ respectively, which was in good agreement with results gained from TGA analysis. The very small hysteresis loops confirmed the superparamagnetism of the yolk-shell $\mathrm{Fe}_{3} \mathrm{O}_{4} @$ PMAA, a good contrast agent for MR imaging.
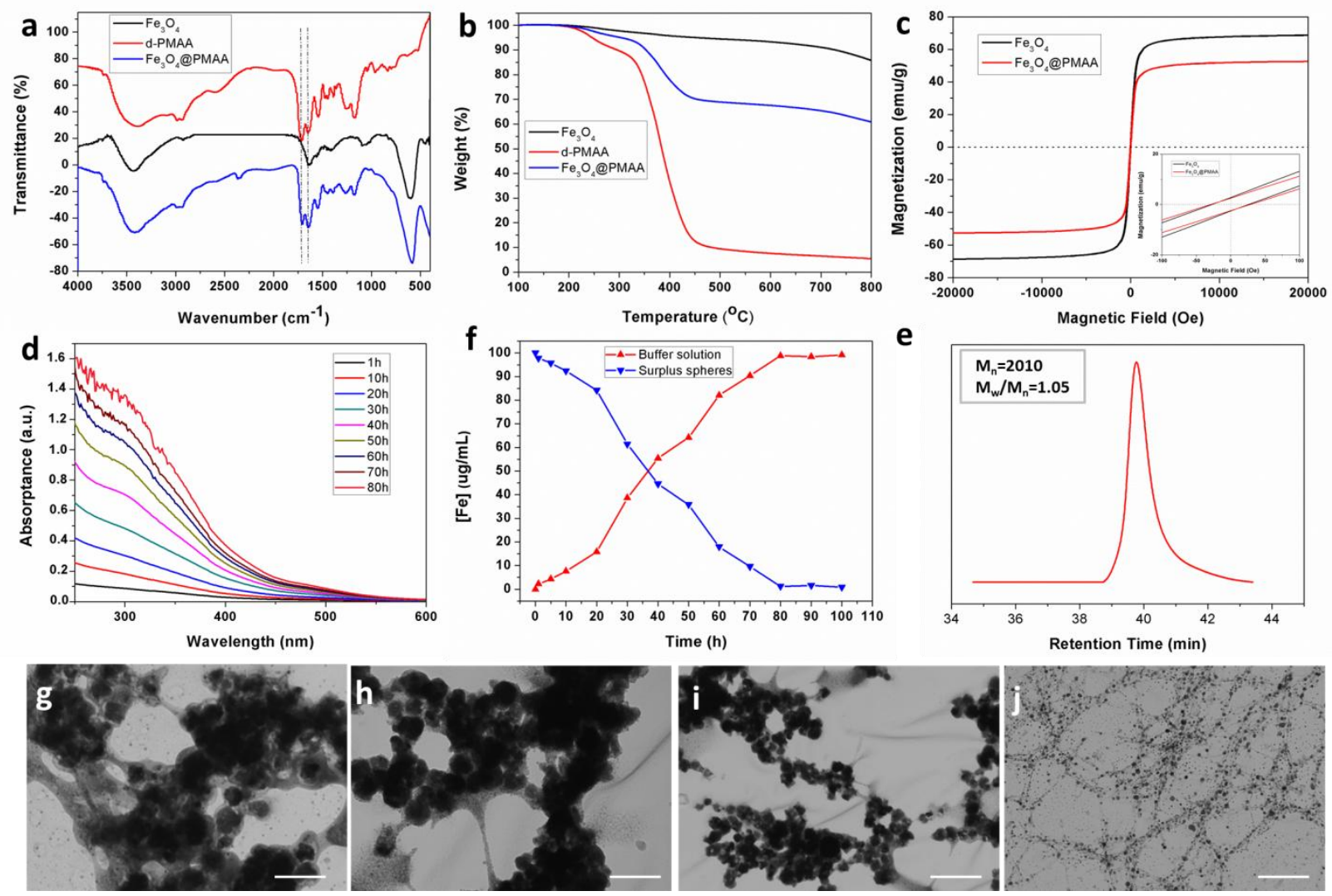
Fig. 2. (a) FTIR spectra and (b) TGA thermograms of PGA-stabilized $\mathrm{Fe}_{3} \mathrm{O}_{4}$ nanoclusters, disulfide cross-linked PMAA (d-PMMA) and yolk-shell $\mathrm{Fe}_{3} \mathrm{O}_{4} @$ PMAA microspheres in $\mathrm{N}_{2}$; (c) The magnetization curves of PGA-stabilized $\mathrm{Fe}_{3} \mathrm{O}_{4}$ nanoclusters and yolk-shell $\mathrm{Fe}_{3} \mathrm{O}_{4} @$ PMAA microspheres. (d) The UV-vis spectra of the $\mathrm{Fe}_{3} \mathrm{O}_{4} @ \mathrm{PMAA}$ in buffer solution after different degradation times; (e) The concentration of iron element in buffer solution and the residual ratio of yolk-shell $\mathrm{Fe}_{3} \mathrm{O}_{4} @$ PMAA versus time; (f) GPC curve of the degraded polymer chains from yolkshell $\mathrm{Fe}_{3} \mathrm{O}_{4} @$ PMAA after degradation for $100 \mathrm{~h}$ under $\mathrm{pH}=5.0$ and $10 \mathrm{mM} \mathrm{GSH}$. TEM images of $\mathrm{Fe}_{3} \mathrm{O}_{4} @$ PMAA at different degradation stages: (g) 1.0 h; (h) 5.0 h; (i) 40.0h; (j) $80.0 \mathrm{~h}$; all bars are $200 \mathrm{~nm}$.

In order to investigate the biodegradability of yolk-shell $\mathrm{Fe}_{3} \mathrm{O}_{4} @ \mathrm{PMAA}$ microspheres, a buffer solution of $\mathrm{Na}_{3} \mathrm{Cit} / \mathrm{H}_{3} \mathrm{Cit}(0.1 \mathrm{~mol} / \mathrm{L}, \mathrm{pH}=5.0)$ with $10 \mathrm{mM}$ glutathione (the intracellular environment with GSH concentration about 2-10 mM) as a reducing agent was chosen to mimic the status of microspheres in an acidic intracellular environment of cancer cells. First, we tested the UV-vis absorption intensity of iron in the solution. The absorption peak of iron ion at $300 \mathrm{~nm}$ became stronger and stronger, illustrating the gradual degradation of $\mathrm{Fe}_{3} \mathrm{O}_{4}$ cores at the condition of $\mathrm{pH}=5.0$ (Fig. 2d). Then, we quantitatively detected the amounts of iron species in the solution and residue at different incubated time through inductively coupled plasma (ICP) to monitor the whole degradation process (Fig. 2e). With the increase of time, the amount of iron component in the solution gradually increased while the amount of iron species in the residue gradually decreased. The $\mathrm{Fe}_{3} \mathrm{O}_{4}$ cores could be dissolved completely after 80 hours. At the same time, the molecular weight of the degraded PMAA shells from $\mathrm{Fe}_{3} \mathrm{O}_{4} @$ PMAA microspheres was measured by Gel Permeation Chromatography (GPC) (Fig. 2f). The GPC result indicted that PMAA 
shells were degraded into linear polymer chains with low molecular weight $\left(M_{n}=2010\right.$ $\mathrm{g} / \mathrm{mol})$ and narrow molecular weight distribution $\left(\mathrm{M}_{\mathrm{w}} / \mathrm{M}_{\mathrm{n}}=1.05\right)$, which was in accordance with our previous report [54,55]. Finally, the morphology of yolk-shell $\mathrm{Fe}_{3} \mathrm{O}_{4} @$ PMAA microspheres in the degradation process was observed by TEM (Fig. 2g-j). When the $\mathrm{Fe}_{3} \mathrm{O}_{4} @$ PMAA microspheres were degraded for 1 hour, the yolk-shell structure of nanosphers still existed, but the PMAA shells started to collapse and formed adhesion. With the degradation time increased to 5 hours, PMAA shells were almost fully degraded, only leaving the $\mathrm{Fe}_{3} \mathrm{O}_{4}$ magnetic cores. With continuous degradation for 40 hours, the size of $\mathrm{Fe}_{3} \mathrm{O}_{4}$ magnetic cores decreased from original 150 $\mathrm{nm}$ to about $50 \mathrm{~nm}$. When the degradation time prolonged for 80 hours, $\mathrm{Fe}_{3} \mathrm{O}_{4}$ clusters degraded to magnetic nanoparticles with just a few nanometers, which was consistent with UV and ICP measurement results. These degradation experiments suggested that both cores and shells of yolk-shell $\mathrm{Fe}_{3} \mathrm{O}_{4} @$ PMAA microspheres could be well biodegraded and excreted to reduce toxicity produced by their accumulation in the body.

\subsection{In vitro drug release kinetics and cell assays}

We chose DOX as a model anti-cancer drug and loaded it into shells of yolk-shell $\mathrm{Fe}_{3} \mathrm{O}_{4} @$ PMAA microspheres (noted as $\mathrm{Fe}_{3} \mathrm{O}_{4} @$ PMAA-DOX) to provide an efficient approach for drug delivery and cancer chemotherapy. Both high drug loading efficiency (91\%) and drug loading capacity (15.4 wt\%) were obtained due to strong electrostatic interactions between carboxyl group and amino group. As we know, there existed some differences in the extracellular and intracellular environments, such as $\mathrm{pH}$ and redox potential. So we conducted the drug-release experiment by dispersing $\mathrm{Fe}_{3} \mathrm{O}_{4} @ \mathrm{PMAA}-\mathrm{DOX}$ to different buffer solutions with different $\mathrm{pH}$ values and GSH 
concentrations. The experimental data in Fig. 3a showed that when the microspheres was subjected to the physiological solution of $\mathrm{pH} 7.4$ without GSH, the amount of released DOX was less than $20 \%$ over a period time of $48 \mathrm{~h}$. After adding $10 \mathrm{mM}$ GSH, the DOX showed a quick release and reached about 71 wt $\%$ after $48 \mathrm{~h}$, further indicating that disulfide-crosslinked PMAA shells was very sensitive to GSH reduction agent. Further, under acidic conditions ( $\mathrm{pH}$ 5.0), this system showed a much faster drug release rate than that in the physiological solution. In the absence of GSH, about $45 \mathrm{wt} \%$ DOX was released from the microspheres after $48 \mathrm{~h}$, which exceeded double release amount in the physiological solution. We got the highest drug release amount in the acidic environment with $10 \mathrm{mM}$ GSH, and the DOX release reached to $80 \mathrm{wt} \%$ within the initial $5 \mathrm{~h}$ due to proton exchange and microspheres destruction. The above cumulative release profile illustrated the yolk-shell $\mathrm{Fe}_{3} \mathrm{O}_{4} @$ PMAA-DOX could effectively release drug under $\mathrm{pH} / \mathrm{GHS}$ dual-stimuli condition.

In vitro cytotoxicity of the yolk-shell $\mathrm{Fe}_{3} \mathrm{O}_{4} @$ PMAA-DOX microspheres on human pancreatic carcinoma (HPAC) cells was investigated via a standard CCK-8 assay using pure $\mathrm{Fe}_{3} \mathrm{O}_{4} @$ PMAA microspheres and free DOX as control. As shown in Fig. 3b, pure $\mathrm{Fe}_{3} \mathrm{O}_{4} @$ PMAA showed no cytotoxicity to HPAC cells after incubation for $24 \mathrm{~h}$ in a wide range concentration $(0.1-100 \mu \mathrm{g} / \mathrm{mL})$. In contrast, both free DOX and $\mathrm{Fe}_{3} \mathrm{O}_{4} @$ PMAA-DOX exhibited an obvious increasing inhibition against HPAC cells with an increased concentration. When the concentration of DOX in $\mathrm{Fe}_{3} \mathrm{O}_{4} @ \mathrm{PMAA}$ DOX increased to $1.0 \mu \mathrm{g} / \mathrm{mL}$, the HPAC cell viability was only $29.4 \%$. As the inhibition time was prolonged to $48 \mathrm{~h}, \mathrm{Fe}_{3} \mathrm{O}_{4} @ \mathrm{PMAA}-\mathrm{DOX}$ exhibited excellent anticancer effect on HPAC cells, even comparable to that of free DOX (Fig. 3c). Almost all of HPAC cells were killed by $\mathrm{Fe}_{3} \mathrm{O}_{4} @$ PMAA-DOX and free DOX at the drug concentration of $1.0 \mu \mathrm{g} / \mathrm{mL}$. Moreover, in vitro cell experiments of human embryonic kidney (HEK) $293 \mathrm{~T}$ cells revealed that pure $\mathrm{Fe}_{3} \mathrm{O}_{4} @$ PMAA had very 
favorable biocompatibility for normal cells (Fig. 3d). After incubation for $24 \mathrm{~h}$ and 48 h, the cell viabilities of HEK $293 \mathrm{~T}$ still remained above $95 \%$ even at a very high nanosphere concentration of $200 \mu \mathrm{g} / \mathrm{mL}$. These results implied that the biodegradable yolk-shell $\mathrm{Fe}_{3} \mathrm{O}_{4} @$ PMAA microspheres had the potential to be used as drug carrier for antitumor nanomedicine.
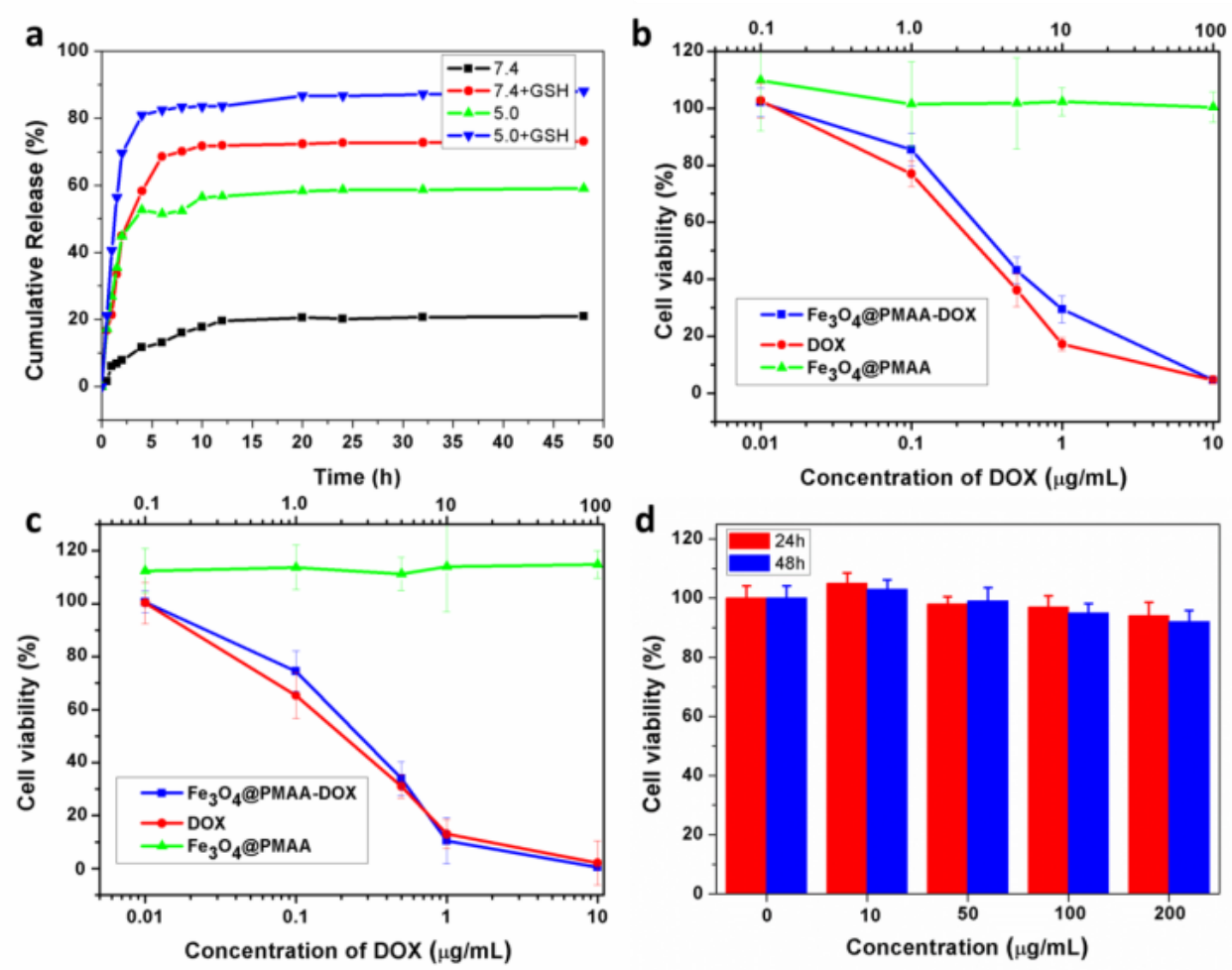

Fig. 3. (a) $\mathrm{pH}$ and redox dual-responsive $\mathrm{DOX}$ release profiles from $\mathrm{Fe}_{3} \mathrm{O}_{4} @ \mathrm{PMAA}-$ DOX under different $\mathrm{pH}$ values and GSH concentrations. Anti-tumor activity of $\mathrm{Fe}_{3} \mathrm{O}_{4} @$ PMAA-DOX microspheres, pure $\mathrm{Fe}_{3} \mathrm{O}_{4} @ \mathrm{PMA}$ and free DOX as a function of DOX dosages for (b) 24 and (c) $48 \mathrm{~h}$ incubation of HPAC cells; the concentration of pure $\mathrm{Fe}_{3} \mathrm{O}_{4} @$ PMAA microspheres (blank control) was shown on the top x-axis. (d) In vitro cell viability of $\mathrm{HEK} 293 \mathrm{~T}$ cells incubated with $\mathrm{Fe}_{3} \mathrm{O}_{4} @ \mathrm{PMAA}$ at different concentrations.

To further verify internalization process of yolk-shell $\mathrm{Fe}_{3} \mathrm{O}_{4} @$ PMAA-DOX microspheres in HPAC cells, the cellular distribution was evaluated using confocal 
laser scanning microscopy (CLSM) analysis. As shown in Fig. 4, red signal of DOX self-fluorescence firstly appeared in the cytoplasm after incubation $2 \mathrm{~h}$, suggesting the $\mathrm{Fe}_{3} \mathrm{O}_{4} @ \mathrm{PMAA}-\mathrm{DOX}$ microspheres passed through the cell membrane to cytoplasm quickly. With the incubation time increased to $6 \mathrm{~h}$, red fluorescence in cytoplasm gradually increased and a little red fluorescence was also observed in the cell nucleus. After $12 \mathrm{~h}$, both fluorescence intensity of DOX in cytoplasm and nucleus obviously enhanced, indicating DOX molecules were effectively released from $\mathrm{Fe}_{3} \mathrm{O}_{4} @ \mathrm{PMAA}$ carriers in acidic intracellular environment and successfully entered nucleus. When the time extended to $24 \mathrm{~h}$, brighter red fluorescence was distributed in the nucleus, suggesting amount of DOX entered nucleus, which was very important to kill tumor cells.

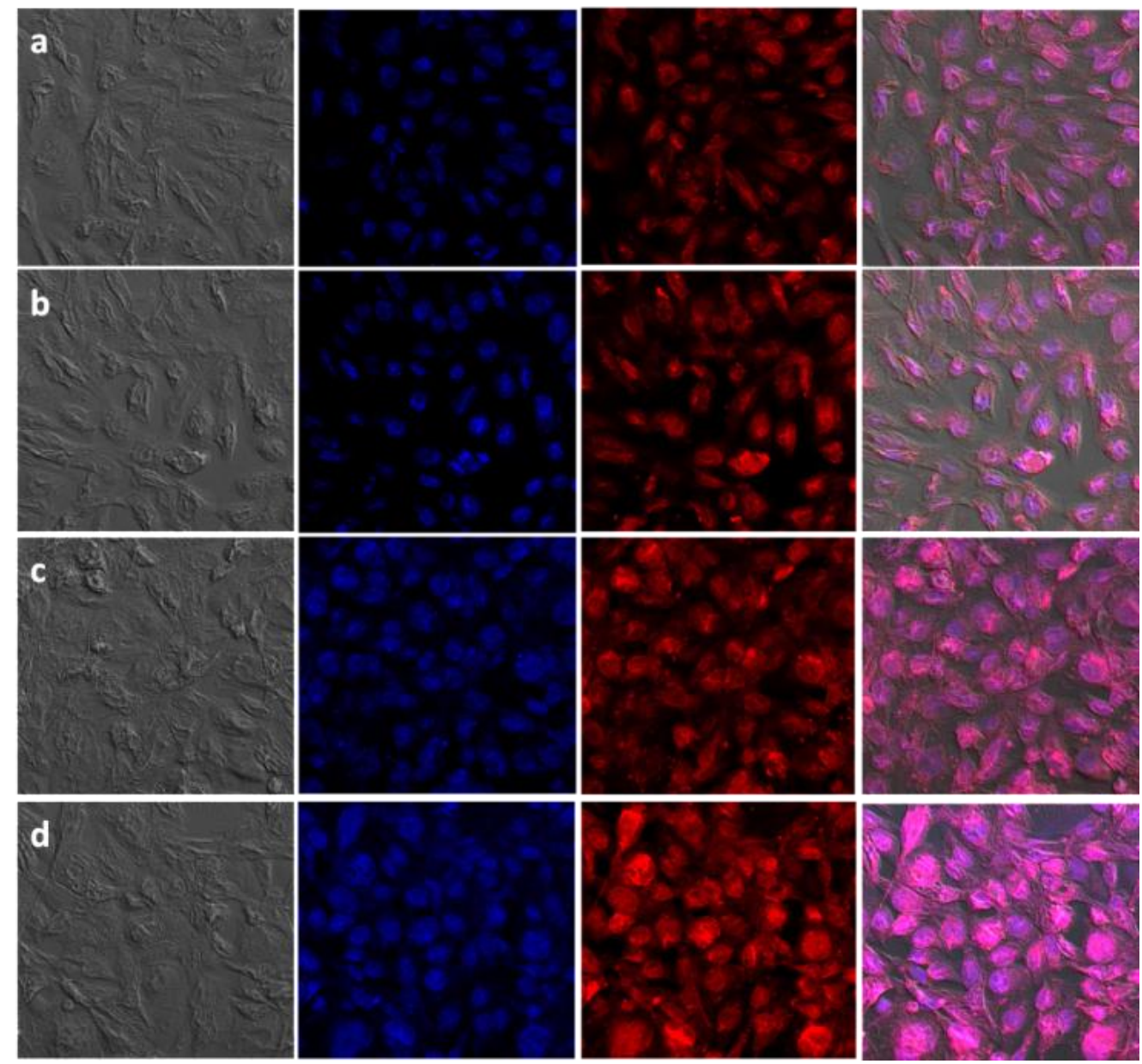


Fig. 4. CLSM images of HPAC cells following (a) $2 \mathrm{~h}$, (b) $6 \mathrm{~h}$ (c) $12 \mathrm{~h}$, (d) $24 \mathrm{~h}$ incubation with DOX-loaded $\mathrm{Fe}_{3} \mathrm{O}_{4} @$ PMAA nanocontainers. For each panel, the images showed bright field, DOX fluorescence in cells (red), cell nuclei stained by Hoechst 33342 (blue), and overlays of the former three images.

\subsection{In vitro ultrasound and MRI evaluation}

In order to enhance the signal of ultrasound imaging, we filled ultrasonic-sensitive biocompatible PFH into the cavities of yolk-shell $\mathrm{Fe}_{3} \mathrm{O}_{4} @$ PMAA-DOX and obtained multifunctional $\mathrm{Fe}_{3} \mathrm{O}_{4} @ \mathrm{PFH} @$ PMAA-DOX microspheres. The PFH could generate highly echogenic phase-transitioned bubbles under ultrasonic wave irritation through acoustic droplet vaporization (ADV) [59]. The digital photos of free $\mathrm{PFH}, \mathrm{Fe}_{3} \mathrm{O}_{4}$ nanoclusters-PFH and $\mathrm{Fe}_{3} \mathrm{O}_{4} @ \mathrm{PFH} @ \mathrm{PMAA}-\mathrm{DOX}$ of the same PFH concentration in phosphate buffered solution (PBS) were recorded (Fig. 5). Compared with pure PFH and $\mathrm{Fe}_{3} \mathrm{O}_{4}$ nanoclusters-PFH, $\mathrm{Fe}_{3} \mathrm{O}_{4} @ \mathrm{PFH} @$ PMAA-DOX solution showed excellent homogeneity and was stable without any PFH precipitation even under magnetic field, indicating PFH molecules have been successfully loaded into cavities of yolk-shell $\mathrm{Fe}_{3} \mathrm{O}_{4} @$ PMAA carriers.

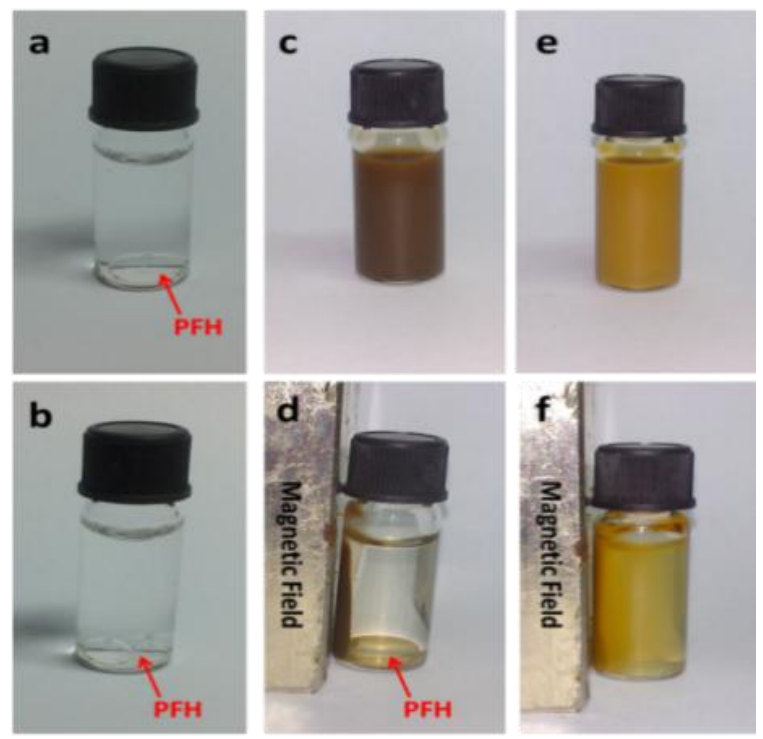


Fig. 5. Digital photos of (a, b) $\mathrm{PFH}$ in PBS solution, (c, d) $\mathrm{Fe}_{3} \mathrm{O}_{4}$ superaparticles/PFH in PBS solution and (e, f) Fe3O4@PFH@PMAA in PBS solution; (d) and (f) were under magnetic field for $30 \mathrm{~s}$.

To investigate the ultrasound effectivity of $\mathrm{Fe}_{3} \mathrm{O}_{4} @ \mathrm{PFH} @$ PMAA-DOX microspheres, in vitro ultrasound imaging was carried out under B-mode and power Doppler imaging mode. As shown in Fig. 6, pure PBS control was almost transparent to ultrasound and had no imaging signal. But introducing pure yolk-shell $\mathrm{Fe}_{3} \mathrm{O}_{4} @$ PMAA microspheres and $\mathrm{Fe}_{3} \mathrm{O}_{4} @ \mathrm{PFH} @$ PMAA-DOX obviously enhanced ultrasound backscatter signal under both B-mode and power Doppler mode. Furthermore, such contrast enhancement of $\mathrm{Fe}_{3} \mathrm{O}_{4} @ \mathrm{PFH} @$ PMAA-DOX was much greater than that of pure yolk-shell $\mathrm{Fe}_{3} \mathrm{O}_{4} @$ PMAA. To better characterize the quantity of imaging signal, we further measured the corresponding average gray values in both B-mode and power Doppler mode. Compared to the PBS control and yolk-shell $\mathrm{Fe}_{3} \mathrm{O}_{4} @ \mathrm{PMAA}$, remarkable increase in average gray scales for $\mathrm{Fe}_{3} \mathrm{O}_{4} @ \mathrm{PFH} @$ PMAADOX were detected under B-mode with the values from 0, 32 to 76 and power Doppler mode from 2, 48 to 154 . Such a significant enhancement of US signal was attributed to high encapsulation capacity of PFH in $\mathrm{Fe}_{3} \mathrm{O}_{4} @ \mathrm{PFH} @$ PMAA-DOX microspheres. In vitro $\mathrm{T}_{2}$-weighted $\mathrm{MR}$ imaging of $\mathrm{Fe}_{3} \mathrm{O}_{4} @ \mathrm{PFH} @ \mathrm{PMAA}-\mathrm{DOX}$ with different iron concentrations (Fe measured by ICP) was measured using 3T MRI human clinical scanner. The MRI signal of $\mathrm{Fe}_{3} \mathrm{O}_{4} @ \mathrm{PFH} @$ PMAA-DOX showed good iron concentration-dependence, with negative enhancement signal as the iron concentration increased (Fig. 6g). Pseudo-colored $\mathrm{T}_{2}$-weighted $\mathrm{MR}$ images are also presented to clearly observe such negative enhancement effect (Fig. 6h). As iron concentration increased, the color in MR images corresponding to signal intensity changed from high to low level. The MRI images of longitudinal sections further showed homogeneous 
signal strength, suggesting the hydrophilic $\mathrm{Fe}_{3} \mathrm{O}_{4} @ \mathrm{PFH} @ \mathrm{PMAA}-\mathrm{DOX}$ microspheres could be dispersed in the aqueous solution uniformly (Fig. 6i). The $T_{2}$-relaxity $\left(r_{2}\right)$ of $\mathrm{Fe}_{3} \mathrm{O}_{4} @ \mathrm{PFH} @ \mathrm{PMAA}-\mathrm{DOX}$ could be obtained from the plotted concentrationdependent relaxation rate $1 / T_{2}\left(R_{2}\right)$ graph. As shown in Fig. $6 \mathrm{j}$, the relaxation rate showed a good linear relationship with the Fe molar concentration. On the basis of the curve slope, the $\mathrm{r}_{2}$ value for $\mathrm{Fe}_{3} \mathrm{O}_{4} @ \mathrm{PFH} @ \mathrm{PMAA}-\mathrm{DOX}$ was calculated to be 71.82 $\mathrm{mM}^{-1} \mathrm{~s}^{-1}$, which ensured their availability as MRI negative contrast agents.

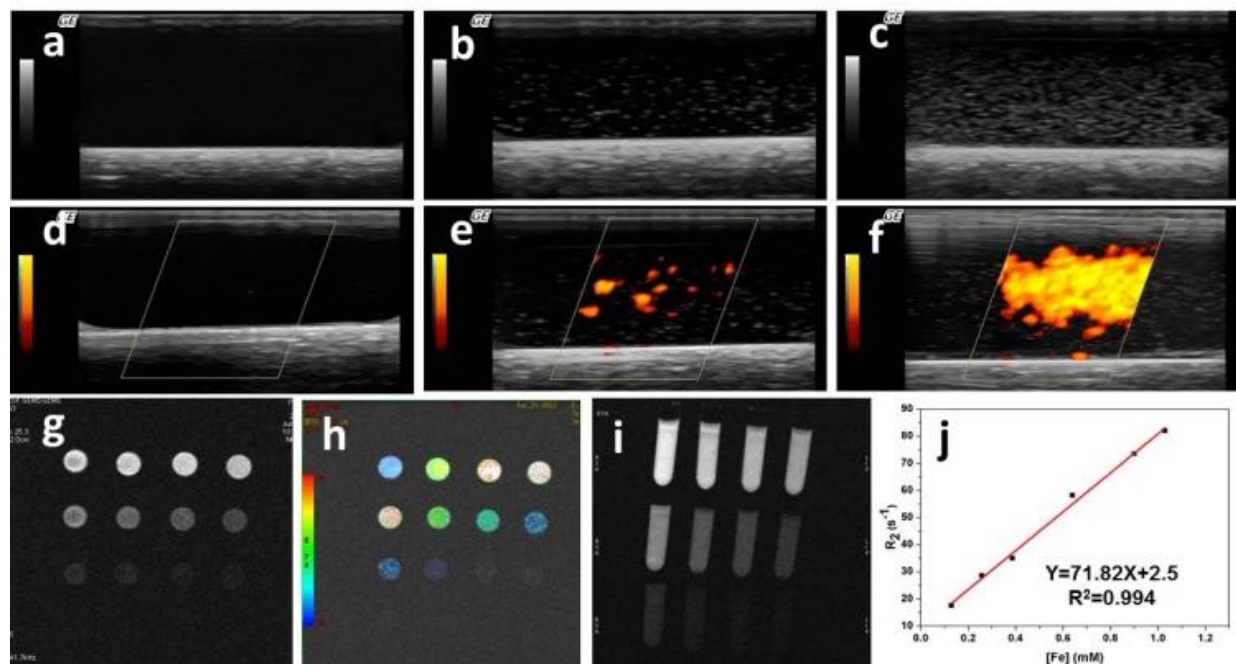

Fig. 6. In vitro US imaging for (a, d) PBS control, (b, e) yolk-shell $\mathrm{Fe}_{3} \mathrm{O}_{4} @ \mathrm{PMAA}$ and (c, f) $\mathrm{Fe}_{3} \mathrm{O}_{4} @$ PFH@PMAA-DOX microspheres in PBS under (a-c) B-mode and (d-f) power Doppler mode. (g) The $\mathrm{T}_{2}$-weighted, (h) pseudo-colored mapped and (i) longitudinal section MR images of $\mathrm{Fe}_{3} \mathrm{O}_{4} @ \mathrm{PFH} @ \mathrm{PMAA}-\mathrm{DOX}$ with various molar concentrations of Fe; (j) Relaxation rate $R_{2}\left(1 / T_{2}\right)$ versus various molar concentrations of $\mathrm{Fe}(0.128,0.257,0.386,0.641,0.902$ and $1.033 \mathrm{mM}$ of $\mathrm{Fe})$.

\subsection{In vivo ultrasound and MRI diagosis}

To further evaluate the effect of tumor diagnosis, in vivo ultrasound and MR imaging of $\mathrm{Fe}_{3} \mathrm{O}_{4} @ \mathrm{PFH} @ \mathrm{PMAA}-\mathrm{DOX}$ was measured using pancreatic tumor-bearing nude mouse as model. As shown in Fig. 7, before injection of microspheres, the 
ultrasound imaging signals in liver and tumor tissues were too low to clearly differentiate the boundary between tumor region and its surrounding liver under both B-mode and power Doppler imaging mode (Fig. 7a, c). After post-intravenous injection of $\mathrm{Fe}_{3} \mathrm{O}_{4} @ \mathrm{PFH} @$ PMAA-DOX by cauda vein, both tumor and liver tissues became brighter and the boundary became clearer, indicating the $\mathrm{Fe}_{3} \mathrm{O}_{4} @ \mathrm{PFH} @$ PMAA-DOX microspheres could successfully enter the tumor tissues due to the poor lymphatic drainage and leaky vasculature in tumor (Fig. 7b, d). In vivo $\mathrm{T}_{2}$-weighted MRI for the whole body further showed that all organs except lung of nude mouse exhibited bright white before injecting $\mathrm{Fe}_{3} \mathrm{O}_{4} @$ PFH@PMAA-DOX (Fig. 7e). Five minutes after the injection, a significant darkening in the liver was first observed due to the microspheres were phagocytosed by reticuloendothelial systems (RES) in liver, which would be very useful for diagnosis of liver abnormalities using MRI technique (Fig. 7f, i). Moreover, after one hour, the microspheres became accumulated in the tumor and a negative enhanced signal was clearly visible in tumor (Fig. 7g, j). 

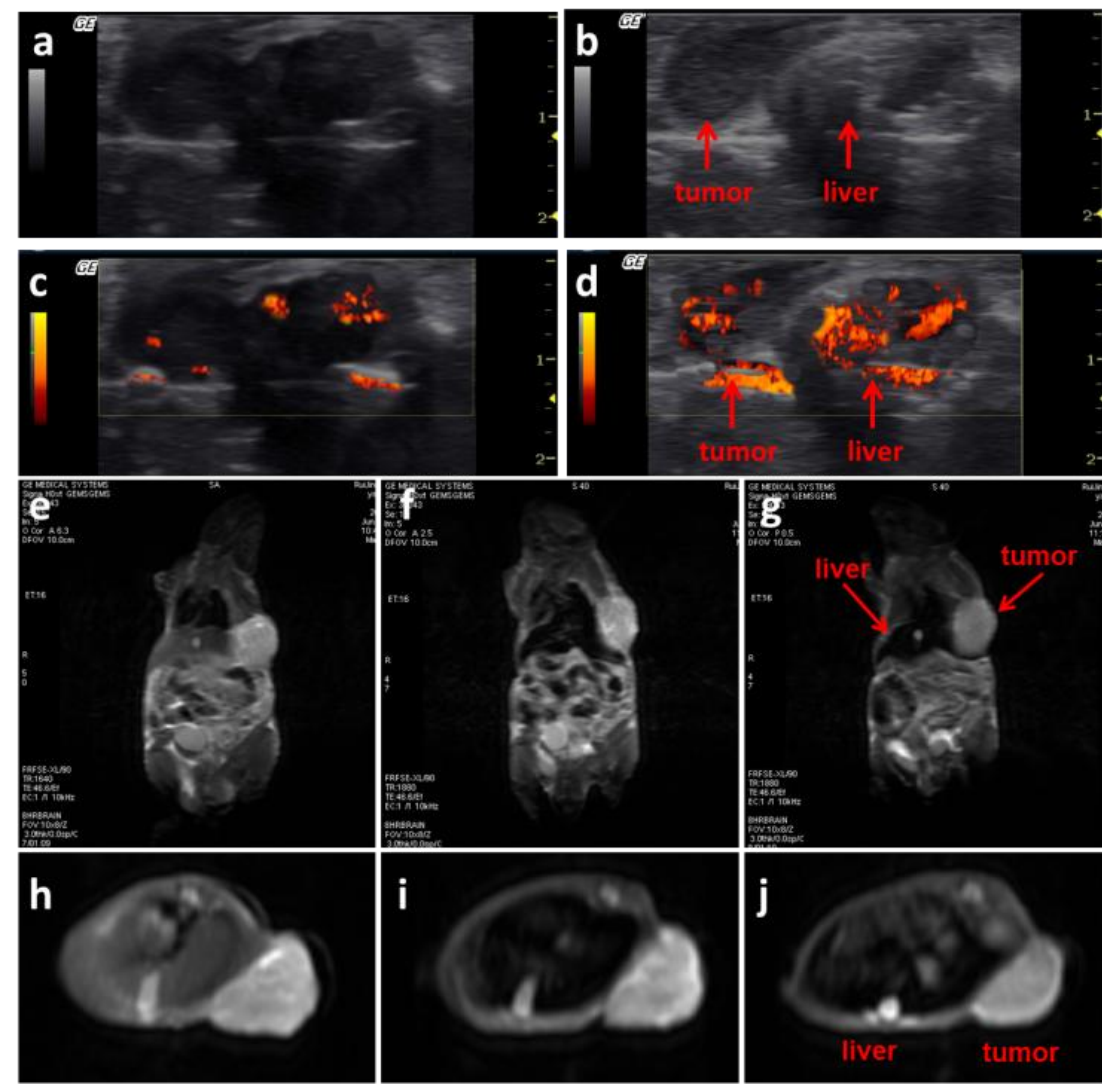

Fig. 7. In vivo ultrasound scan of tumor and liver of nude mouse bearing pancreatic tumor $(\mathrm{a}, \mathrm{c})$ before and $(\mathrm{b}, \mathrm{d})$ after injection of $\mathrm{Fe}_{3} \mathrm{O}_{4} @ \mathrm{PFH} @$ PMAA-DOX microspheres under $(\mathrm{a}, \mathrm{b}) \mathrm{B}$-mode and $(\mathrm{c}, \mathrm{d})$ power Doppler mode. In vivo MRI of nude mouse bearing pancreatic tumor $(e, h)$ before and after (f, i) 5 min and (e, j) 60 min injection of $\mathrm{Fe}_{3} \mathrm{O}_{4} @ \mathrm{PFH} @ \mathrm{PMAA}-\mathrm{DOX}$ microspheres.

\subsection{Tumor histological biopsies and TEM observation}

In order to better observe aggregation of microspheres in the tumor site and treatment effect of tumor, we firstly injected $\mathrm{Fe}_{3} \mathrm{O}_{4} @$ PFH@PMAA-DOX into pancreatic tumor-bearing nude mouse and then some tumor tissues were studied for histological biopsies and TEM observation after injection 3 days. 

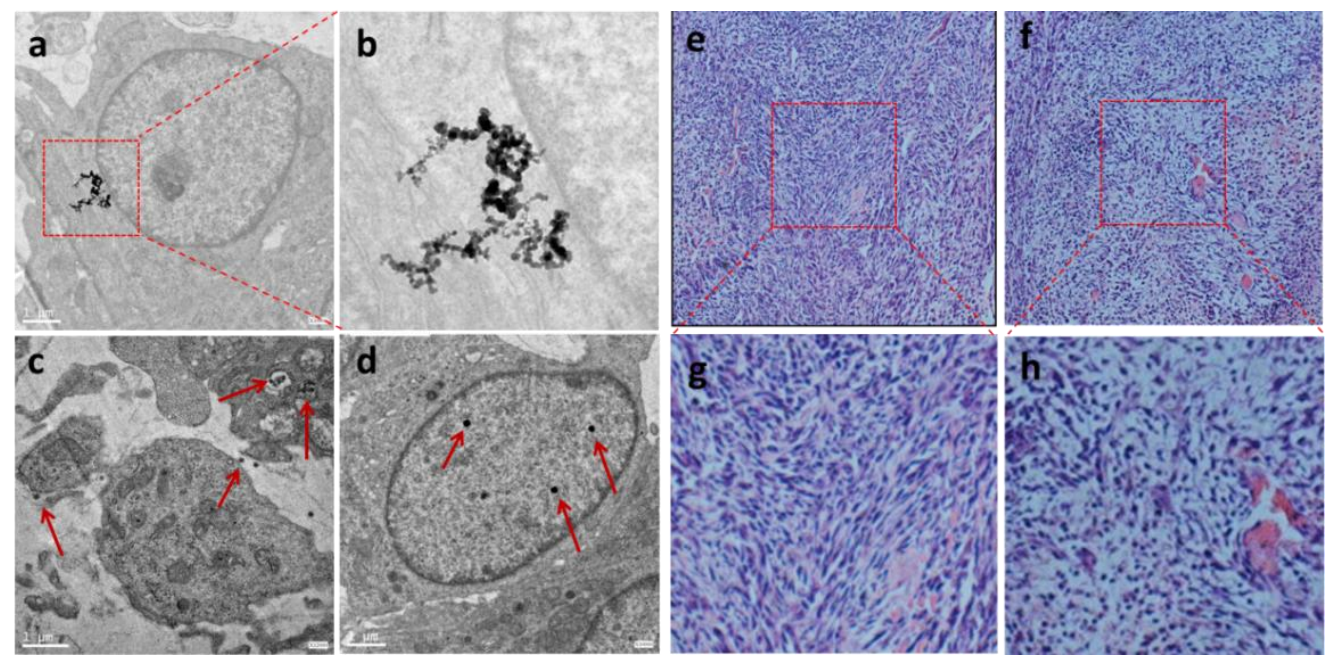

Fig. 8. (a-d) TEM images of tumor slices after injection of $\mathrm{Fe}_{3} \mathrm{O}_{4} @ \mathrm{PFH} @ \mathrm{PMAA}$ for 3 days; H\&E-stained tumor histological biopsies collected from mice (e, g) before and (f, h) after injection of $\mathrm{Fe}_{3} \mathrm{O}_{4} @ \mathrm{PFH} @ \mathrm{PMAA}-\mathrm{DOX}$ for 3 days.

TEM images of tumor slices showed plenty of $\mathrm{Fe}_{3} \mathrm{O}_{4} @$ PMAA microspheres gathered in tumor cells (Fig. 8a-d). At the same time, PMAA shells began to degrade and appeared adhesion, and $\mathrm{Fe}_{3} \mathrm{O}_{4}$ cores were disjointed from the shells (Fig. 8b). Some $\mathrm{Fe}_{3} \mathrm{O}_{4}$ clusters were also found in intercellular substance (Fig. 8c), suggesting that as-prepared $\mathrm{Fe}_{3} \mathrm{O}_{4} @ \mathrm{PMAA}$ microspheres could be successfully enriched in the tumor site and further be degraded in the tumor cells. The tumor histological biopsies were firstly stained with hematoxylin and eosin $(\mathrm{H} \& \mathrm{E})$ and then analyzed under the optical microscope. As shown in Fig. 8e, normal pancreatic tumor cells closely arranged and the structure of the nucleus and cytoplasm maintained integrity. After injecting $\mathrm{Fe}_{3} \mathrm{O}_{4} @ \mathrm{PFH} @ \mathrm{PMAA}-\mathrm{DOX}$ microspheres, tumor cells began to rupture and the nuclei fell off from the cytoplasm, illustrating $\mathrm{Fe}_{3} \mathrm{O}_{4} @ \mathrm{PFH} @$ PMAA-DOX could effectively release DOX and kill the tumor cells in the body (Fig. 8f, h). Therefore, it is anticipated that the biodegradable $\mathrm{Fe}_{3} \mathrm{O}_{4} @$ PFH@PMAA-DOX microspheres would be 
a good theranostic nanoplatform as ultrasound and MRI dual-modality imaging contrast agents and drug carriers for diagnosis and therapy of cancer.

\section{Conclusions}

In summary, we have demonstrated a simple strategy to fabricate uniform yolk-shell $\mathrm{Fe}_{3} \mathrm{O}_{4} @$ PMAA microspheres using reflux-precipitation polymerization, which could be used as robust ultrasound and MRI dual-modality imaging contrast agents through effectively encapsulating PFH into the cavities as ultrasound bubble generator. In addition, the functional PMAA shells had great DOX-loading capability (15.4 wt\%) and excellent drug loading efficiency $(91 \%)$ by strong electrostatic interactions between carboxyl groups and amino groups, and the loaded drug could be rapidly released in cancer cells under GSH and $\mathrm{pH}$ dual-stimulus response. The biocompatible $\mathrm{Fe}_{3} \mathrm{O}_{4} @ \mathrm{PFH} @$ PMAA-DOX microspheres with good hydrophilicity were dispersed uniformly and stably in the PBS solution, along with relative stable US/MRI signal intensity and high $r_{2}$ value of $71.82 \mathrm{mM}^{-1} \mathrm{~s}^{-1}$. In vivo imaging experiments and tumor tissues biopsies indicated the as-prepared $\mathrm{Fe}_{3} \mathrm{O}_{4} @ \mathrm{PFH} @$ PMAA-DOX microspheres could easily reach the tumor tissues and then killed cancer cells effectively, ensuring the great potential of $\mathrm{Fe}_{3} \mathrm{O}_{4} @ \mathrm{PFH} @ \mathrm{PMAA}-\mathrm{DOX}$ microspheres as multifunctional platform for cancer diagnosis and therapy. What is more, the disulfide-crosslinked PMAA shells and PGA-stabilized $\mathrm{Fe}_{3} \mathrm{O}_{4}$ cores could be simultaneously degraded to short hydrophilic polymer chains and iron ions in body and then effectively excreted, reducing the toxicity of the agents caused by their accumulation in organisms. Thus, the multifunctional biodegradable microspheres were safer for normal tissues and more beneficial to actual clinical applications.

\section{Acknowledgements}


This work was supported by State Key Project of Research and Development (Grant No. 2016YFC1100300) and National Science Foundation of China (Grant No 21474017, $51603042)$.

\section{REFERENCES}

[1] G. F. Cheng, Adv. Drug Delivery Rev. 81 (2015) 75-93.

[2] H. Ma, J. P. Liu, M. M. Ali, M. A. Mahmood, L. Zabazieh, M. Lu, S. M. Lqbal, Q. Zhang, W. A. Zha, Y. Wan, Chem. Soc. Rev. 44 (2015) 1240-1256.

[3] K. E. Sapsford, W. R. Algar, L. Berti, K. B. Gemmill, B. J. Casey, E. Oh, M. H. Stewart, I. L. Medintz, Chem. Rev. 113 (2013) 1904-2074.

[4] D. L Shi, N. M. Bedford, H. S. Cho, Small 7 (2014) 2549-2567.

[5] J. V. Jokerst, T. Lobovkina, R. N. Zare, S. S. Gambhir, Nanomedicine 6 (2015) $715-728$.

[6] D. E. Lee, H. Koo, I. C. Sun, J. H. Ryu, K. Kim, I. C. Kwon, Chem. Soc. Rev. 2012, 41, 2656-2672.

[7] Z. Liu, J. Liu, R. Wang, Y. Da, J. Ren, X. Qu, Biomaterials 2015 56, 206-218.

[8] H. Iqbal, S. Robin, P. Humbert, C. Viennet, G. Agusti, H. Fessi, A. Elaissari, Colloids Surf. B $136(2015)$ 488-495.

[9] M. A. Pysz, S. S. Gambhir, J. K. Willmann, Clin. Radiol. 65 (2010) 500-506.

[10] J. Rieffel, U. Chitgupi, J. F. Lovell, Small 11 (2015) 4445-4461.

[11] A. Louie, Chem. Rev. 110 (2014) 3146-3195.

[12] H. C. Zhang, X. Ma, K. T. Nguyen, Y. L. Zhao, ACS Nano 7 (2013) 7853-7863.

[13] S. Mitragotri, J. Kost, Adv. Drug Deliv. Rev. 56 (2014) 589-601.

[14] S. J. Warden, R. K. Fuchs, C. K. Kessler K. G. Avin, R. E. Cardinal, R. L. Stewart, Phys. Ther. 86 (2006) 1118-1127. 
[15] N. Deshpande, A. Needles, J. K. Willmann, Clin. Radiol. 65 (2010) 567-581.

[16] P. J. Bassera, C. Pierpaoli, J. Magn. Reson. 213 (2013) 560-570.

[17] M. Modo, M. Hoehn, J. W. Bulte, J. W. Mol. Imaging 4 (2015) 143-164.

[18] P. Caravan, Chem. Soc. Rev. 35 (2006) 512-523.

[19] V. Mirabello, D. G. Calatayud, R. L. Arrowsmith, H. Ge, S. I. Pascu, J. Mater. Chem. B 3 (2015) 5657-5672.

[20] J. R. Lindner, Nat. Rev. Drug Discov. 3 (2004) 527-532.

[21] S. Qin, S.; C. F. Caskey, K. W. Ferrara, Phys. Med. Biol. 54 (2009) R27-R57.

[22] Z. Zha, S. Wang, S. Zhang, E. Qu, H. Ke, J. Wang, Z. Dai, Nanoscale, 5 (2013) 3216-3219.

[23] E. G. Schutt, D. H. Klein, R. M. Mattrey, J. G. Riess, Angew. Chem. Int. Ed. 42 (2003) 3218-3235.

[24] E. Quaia, F. Calliada, M. Bertolotto, S. Rossi, L. Garioni, L. Rosa, Radiology 232 (2004) 420-430.

[25] H. Yang, W. Cai, L. Xu, X. Lv, Y. Qiao, P. Li, H. Wu, Y. Yang, L. Zhang, Y. Y. Duan, Biomaterials 37 (2015) 279-288.

[26] J. O. Eloy, M. C. de Souza, R. Petrilli, J. P. A. Barcellos, R. J. Lee, J. M. Marchetti, Colloids Surf. B 123 (2014) 345-363.

[27] Z. Xing, J. Wang, H. Ke, B. Zhao, X. Yue, Z. Dai, Nanotechnology 21 (2010) 145607

[28] P. L. Lin, R. J. Eckersley, E. A. Hall, Adv. Mater. 21 (2009) 3949-3952.

[29] L. Han, P. Xiong, J. F. Bai, S. A. Che, J. Am. Chem. Soc. 133 (2011) 6106-6109.

[30] P. Yang, J. Ding, J. Guo, W. B. Shi, J. Hu, C. C. Wang, J. Mater. Chem. B 1 (2013) $544-551$

[31] T. Shin, Y. Choi, S. Kim, J. Cheon, Chem. Soc. Rev. 44 (2015) 4501-4516. 
[32] N. Lee, D. Yoo, D. Ling, M. Cho, T. Hyeon, J. Cheon, Chem. Rev. 115 (2015) 10637-10689.

[33] J. Guo, W. L. Yang, C. C. Wang, Adv. Mater. 25 (2013) 5196-5214.

[34] S.V. German, N.A. Navolokin, N.R. Kuznetsova, V.V. Zuev, O.A. Inozemtseva, A.A. Aniskov, E.K. Volkova, A.B. Bucharskaya, G.N. Maslyakova, R.F. Fakhrullin, G.S. Terentyuk, E.L. Vodovozova, D.A. Gorin, Colloids Surf. B 135 (2015) 109-115.

[35] A. Moussaron, S. Vibhute, A. Bianchi, S. Gündüz, S. Kotb, L. Sancey, V. MottoRos, S. Rizzitelli, Y. Crémillieux, F. Lux, N. K. Logothetis, O. Tillement, G. Angelovski, Small 11 (2015) 4900-4909.

[36] S. Palchoudhury, Y. L. Xu, A. Rushdi, R. A. Holler, Y. P. Bao, Chem. Commun. 48 (2012) 10499-10501.

[37] J. Hwang, E. Lee, J. Kim, Y. Seo, K. H. Lee, J. W. Hong, A. A. Gilad, H. Park, J. Choi, Colloids Surf. B 142 (2016) 290-296.

[38] F. Wang, G. M. Pauletti, J. T. Wang, J. M. Zhang, R. C. Ewing, Y. L. Wang, D. L. Shi, Adv. Mater. 25 (2013) 3485-3489.

[39] F. Yang, X. Y. Li, Z. P. Chen, Y. Zhang, J. R. Wu, N. Gu, Biomaterials 30 (2009) 3882-3890;

[40] Z. Liu, T. Lammers, J. Ehling, S. Fokong, J. Bornemann, F. Kiessling, Biomaterials 32 (2011) 6155-6163.

[41] Y. Sun, Y. Zheng, H. Ran, Y. Zhou, H. Shen, Y. Chen, H. Chen, T. M. Krupka, A. Li, P. Li, Z. Wang, Biomaterials 33 (2012) 5854-5864.

[42] C. Pereira, A. M. Pereira, M. Rocha, C. Freire, C. Geraldes, J. Mater. Chem. B, 3 (2015) 6261-6273.

[43] N. Rapoport, Z. Gao, A. Kennedy, J. Natl. Cancer Inst. 99 (2007) 1095-1106. 
[44] S. K. Hobbs, W. L. Monsk, F. Yuan, W. G. Roberts, L. Griffith, V. P. Torchilin, R. K. Jain, Proc. Natl. Acad. Sci. USA 95 (1998) 4607-4612.

[45] H. Maeda, J. Wu, T. Sawa, Y. Matsumura, K. Hori, J. Control. Release 65 (2010) 271-284.

[46] P. Yang, F. Wang, X. F. Luo, Y. T. Zhang, J. Guo, W. B. Shi, C. C. Wang, ACS Appl. Mater. Interfaces 6 (2014) 12581-12587.

[47] J. Panyam, V. Labhasetwar, Adv. Drug Deliv. Rev. 64 (2012) 61-71.

[48] H. S. Choi, W. Liu, P. Misra, E. Tanaka, J. P. Zimmer, B. I. Ipe, M. G. Bawendi, J. V. Frangioni, Nat. Biotechnol. 25 (2007) 1165-1170.

[49] C. H. Wang, S. T. Kang, C. K. Yeh, Biomaterials 34 (2013) 1852-1861.

[50] H. Y. Huang, S. H. Hu, S. Y. Hung, C. S. Chiang, H. L. Liu, T. L. Chiou, H. Y. Lai, Y. Y. Chen, S. Y. Chen, J. Control. Release 172 (2013) 118-127.

[51] C. A. Poland, R. Duffin, I. Kinloch, A. Maynard, W. A. Wallace, A. Seaton, V. Stone, S. Brown, W. MacNee, K. Donaldson, Nat. Nanotechnol. 3 (2008) 423-427.

[52] A. M. Derfus, W. C. Chan, S. N. Bhatia, Nano Lett. 4 (2004) 11-18.

[53] B. Luo, S. Xu, A. Luo, W. R. Wang, S. L. Wang, J. Guo, Y. Lin, D. Y. Zhao, C. C. Wang, ACS Nano 5 (2011) 1428-1435.

[54] Y. J. Pan, Y. Y. Chen, D. R. Wang, C. Wei, J. Guo, D. R. Lu, C. C. Chu, C. C. Wang, Biomaterials, 33 (2012) 6570-6579.

[55] P. Yang, D. Li, S. Jin, J. Ding, J. Guo, W. B. Shi, C. C. Wang, Biomaterials 35 (2014) 2079-2088.

[56] S. Jin, Y. J. Pan, C. C. Wang, Acta Chim. Sinica 71 (2013) 1500-1504.

[57] X. Wang, X. H. R. Chen, Y. Chen, M. Ma, K. Zhang, F. Q. Li, Y. Y. Zheng, D. P. Zeng, Q. Wang, J. L. Shi, Adv. Mater. 24 (2012) 785-791.

[58] K. H. Nam, D. A. Christensen, A. M. Kennedy, N. Rapoport, Am. Inst. Phys. Conf. Proc. 1113 (2009) 124-128. 
[59] O. D. Kripfgans, J. B. Fowlkes, D. L. Miller, O. P. Eldevik, P. L. Carson, Ultrasound Med. Biol. 26 (2000) 1177-1189. 
Graphical Abstract

Graphical abstract

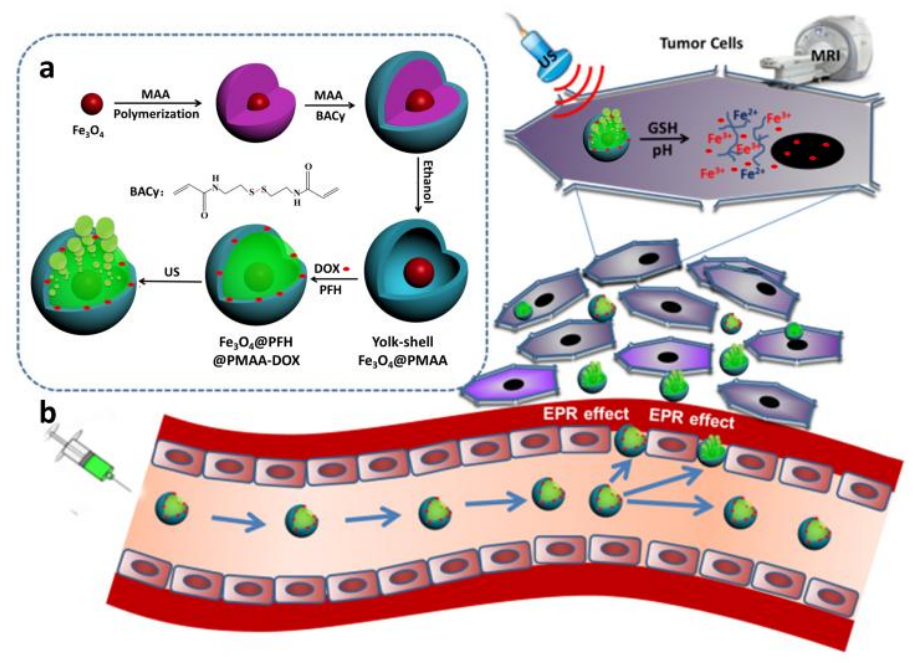

